\title{
Investigation of Morphology, Size Distribution and Surface Area of ZnO Crystallization Using Taguchi Experimental Design
}

\author{
Muhammed Bora Akın ${ }^{1 *}$, Ömer Faruk Dilmaç², Barış Şimşek ${ }^{3}$ \\ 1* Çankırı Karatekin University, Departmant of Chemical Engineering, Çankırı, Turkey, (ORCID: : 0000-0003-3841-1633), mbakin@karatekin.edu.tr \\ ${ }^{2}$ Çankırı Karatekin University, Departmant of Chemical Engineering, Çankırı, Turkey, (ORCID: 0000-0002-9660-0638), ofdilmac@karatekin.edu.tr \\ ${ }^{3}$ Çankırı Karatekin University, Departmant of Chemical Engineering, Çankırı, Turkey, (ORCID: 0000-0002-0655-4368), barissimsek@karatekin.edu.tr
}

(2nd International Conference on Applied Engineering and Natural Sciences ICAENS 2022, March 10-13, 2022)

(DOI: 10.31590/ejosat.1082634)

ATIF/REFERENCE: Akin, M.B., Dilmac, Ö.F., \& Simsek, B. (2022). Investigation of Morphology, Size Distribution and Surface Area of ZnO Crystallization Using Taguchi Experimental Design. European Journal of Science and Technology, (34), 367-373.

\begin{abstract}
Length, width and specific surface area are among the important criteria representing $\mathrm{ZnO}$ crystallization. The average width, average length and surface area of the synthesized $\mathrm{ZnO}$ crystals are important because they directly change the application area in which the material will be used. In this study, the factors affecting these criteria were determined as the amount of poly(sodium 4-styrenesulfonate), ultrasonication power, reactant concentration and reaction temperature. The effects of the factors on the selected criteria are analyzed and determined using the Taguchi experimental design method and main effect analysis. The results showed that if the $\mathrm{ZnO}$ crystals to be produced are to be used as catalysts, a lower PSSS concentration should be preferred for the synthesis of these crystals, which are smaller in size and have a larger surface area. Another result is; It is seen that the amount of additive and ultrasonication are the two most effective parameters on the average width, average length and specific surface area properties of the synthesized $\mathrm{ZnO}$ crystals.
\end{abstract}

Keywords: Zinc oxide, Crystallization, Additive, PSSS, Ultrasonication, Taguchi method.

\section{ZnO Kristalizasyonunun Morfolojisi, Boyut Dağılımı ve Yüzey Alanının Taguchi Deneysel Tasarımı Kullanılarak İncelenmesi}

\begin{abstract}
Öz
Uzunluk, genişlik ve spesifik yüzey alanı ZnO kristalizasyonunu temsil eden önemli kriterler arasında bulunur. Sentezlenen ZnO kristallerinin ortalama genişliği, ortalama uzunluğu ve yüzey alanı malzemenin kullanılacağı uygulama alanını direkt olarak değiştirdiği için önemlidir. Bu çalışmada bu kriterleri etkileyen faktörler olarak poli(sodyum 4-stirensülfonat) (PSSS) miktarı, ultrasonikasyon gücü, reaktan konsantrasyonu ve reaksiyon sıcaklığı belirlenmiştir. Faktörlerin seçilen kriterler üzerindeki etkileri, Taguchi deney tasarımı yöntemi ve ana etki analizi kullanılarak analiz edilmekte ve tespit edilmektedir. Sonuçlar, Üretilecek ZnO kristallerinin katalizörler olarak kullanımı söz konusu ise, boyut olarak daha küçük ve yüzey alanı daha büyük olan bu kristallerin sentezi için daha düşük PSSS konsantrasyonunun tercih edilmesi gerektiğini göstermiştir. Bir diğer sonuç ise; sentezlenen ZnO kristallerinin ortalama genişlik, ortalama uzunluk ve spesifik yüzey alanı özellikleri üzerinde katkı miktarı ve ultrasonikasyonun en etkili iki parametre olarak karşımıza çıktığı görülmektedir.
\end{abstract}

Anahtar Kelimeler: Çinko oksit, Kristalizasyon, Katkı, PSSS, Ultrasonikasyon, Taguchi metodu.

${ }^{*}$ Corresponding Author: mbakin@karatekin.edu.tr 


\section{Introduction}

Zinc oxide $(\mathrm{ZnO})$ emerges as a material with a wide range of uses, where piezoelectric (Yang and Kim, 2021), photocatalytic (Akin and Oner, 2013) and antimicrobial (Akin and Akyüz, 2020) properties are emphasized. The combination of semiconductor and piezoelectric properties makes it unique. There is a necessity to control the morphology and dimensions according to the areas where it is used. It has been possible to synthesize nano- or micron-sized $\mathrm{ZnO}$ crystals of varying morphologies, under certain conditions, by different methods: combs, rings, coils, springs, belts, wires etc. Additives stand before us as the most effective method in controlling crystal size and morphology.

Chemical precipitation method plays an important role especially in the synthesis of metal oxides. In addition to being inexpensive, it is easy to apply at low temperature and allows finetuning of material properties during crystallization.

In one study, while $\mathrm{ZnO}$ nanoparticles were synthesized by chemical precipitation method, this process was clarified. The nanoparticles synthesized in the study are characterized using TEM, EDS, XRD, Raman and FTIR spectroscopy, and it has been revealed that the size is around $30 \mathrm{~nm}$. It was formed in the pure hexagonal-wurtzite phase of $\mathrm{ZnO}$ nanocrystals (Sahai and Goswami, 2014). In another study, nanocrystalline $\mathrm{ZnO}$ powders, were successfully synthesized at four different $\mathrm{pH}$ values by chemical precipitation method. In this way, the role of the $\mathrm{pH}$ value of the solution is revealed. It has been proven that the $\mathrm{pH}$ value is effective on various properties of $\mathrm{ZnO}$ nanoparticles synthesized by chemical precipitation. It was seen that the crystalline synthesized by XRD and SEM analyzes was wurtzite. In addition, since the UV-Vis absorption of $\mathrm{ZnO}$ nanoparticles synthesized at $\mathrm{pH}=6$ is higher than the other, it has been revealed that it can be used as a UV absorber (Chithra et al., 2015). In another study, chitosan (CHT)-ZnO nanocomposites were synthesized using chemical precipitation method. In addition, CHT-ZnO-TiO ${ }_{2}$ composites have been synthesized also. Observed CHT, $\mathrm{ZnO}$ and $\mathrm{TiO}_{2}$ patterns in the XRD analysis of the samples are proved that the samples were prepared successfully. DLS analysis results that the average particle size of $\mathrm{ZnO}$ nanoparticles was $18 \mathrm{~nm}$. Also, antibacterial activity tests were done these samples. The results showed strong antibacterial activity for the cotton sample treated with CHT-ZnO nanocomposite compared to the untreated and CHT cut treated fabric. SEM-EDS analysis has been used to prove the found by $\mathrm{ZnO}$ and $\mathrm{TiO}_{2}$ nanoparticles on the cotton fabric surface. The findings prove the use of fabrics treated with CHT-ZnO nanocomposite in the areas where antimicrobial and UV protective functions are needed (Turemen et al., 2021). In another study, $\mathrm{ZnO}$ nanoparticles were synthesized at low temperature chemical precipitation method, and it was revealed that both the structural and optical properties of the obtained $\mathrm{ZnO}$ products depend on the annealing temperature. The XRD results revealed that the crystallite sizes increase with increase in annealing temperature. It is reason that the coalescence of smaller crystallites at high temperatures. SEM images showed that the particles became almost spherical by agglomeration and increased in size with increasing temperature (Goswami et al., 2018).

There are different methods to synthesize materials by changing their properties: additives, selected production method, reactants, reaction temperature, initial $\mathrm{pH}$, initial concentration of reactants, reaction media etc. During the production of $\mathrm{ZnO}$ e-ISSN: 2148-2683 materials, its properties can be controlled easily with additives added to the medium. Additives vary depending on the property of the substance to be changed. In general, the literature is examined, it is seen that metals, metal oxides and polymers are used as additives. Even a small amount of additive used can change the material properties, and composite production is realized with the increase in the amount of additive.

Sun et al. (2011) showed that modified $\mathrm{ZnO}$ nanorods is synthesized using gold nanoparticles as additive and thus it is improved the photocatalytic activity. Akin and Oner (2012) obtain by a simple wet chemical method using zinc nitrate hexahydrate and hexamethylenetetramine as the starting materials in the presence of carboxymethyl inulin (CMI). Effect on the morphology, surface area, particle size, and size distribution of zinc oxide has been investigated with changed reaction temperature and CMI concentration. X-ray diffraction analyses showed the XRD patterns of synthesized materials were similar the wurtzite structure. The investigated $\mathrm{ZnO}$ material consisted of micrometer-sized hexagonally shaped bipyramidal crystals and nanocrystals. Palms et al. (2007) investigated the crystallization kinetics of zinc oxide in the presence of different polymers according to the amperometry theory. They found that the polymeric materials used as additives significantly changed the morphology of the $\mathrm{ZnO}$ films as they affected the relative growth rate of the crystal faces.

Although mechanical or magnetic stirring is sufficient, ultrasonic sound waves are also used for homogenization of solutions in some applications. The application of ultrasonic sound waves among alternative metal oxide material production methods is called sonochemical method. Sonochemical method is preferred because it provides fast material production. In a study by Pholnak et al., while synthesizing zinc oxide nanoparticles, solutions in glass containers of various shapes, such as cubes, cylinders, and spheres, were produced by sonicating with a $45 \mathrm{~W}$ $20 \mathrm{kHz}$ ultrasonic pulse for 60 minutes under ambient conditions. A commercial ultrasonic homogenizer was used in the sonochemical reaction used here. Average particle diameters of about $70 \mathrm{~nm}$ were confirmed by crystalline $\mathrm{ZnO}$ phase, powder $\mathrm{X}$-ray diffraction, and scanning electron microscopy (Pholnak et al., 2013). By Intaphong et al., heterostructured $\mathrm{Pd} / \mathrm{ZnO}$ nanocomposites with different weight $\mathrm{Pd}$ contents were synthesized by sonochemical assisted deposition method and they have been successful in removing dyestuffs for photocatalysis using UV radiation (Intaphong et al., 2021). Bao et al. have presented a simple route of the ethylene glychol-assisted sonochemical method for fabricating highly crystalline $\mathrm{ZnO}$ twinsphere-like, hexagonal-prism-like, and bouquet-like. In this route, water content, alkaline medium, reaction $\mathrm{pH}$, and ultrasound time were came forward key factors in the morphology control of $\mathrm{ZnO}$. It was observed that higher water content increased the growth rate and incorporation of $\mathrm{ZnO}$ (Bao et al.. 2021) In another study, Satdeve et al. (2019) sonochemically produced $\mathrm{ZnO}$ nanoparticles and $\mathrm{Ag}-\mathrm{ZnO}$ nanocomposite. The mean crystallite size of $\mathrm{ZnO}$ nanoparticles and $\mathrm{Ag}-\mathrm{ZnO}$ nanocomposite prepared were found to be $17.525 \mathrm{~nm}$ and $18.725 \mathrm{~nm}$, respectively. Photocatalytic activity and properties of the synthesized photocatalysts were investigated by using the decolorization of $\mathrm{MB}$ dye under sunlight.

$\mathrm{Yu}$ et al. (2008) synthesized and investigated $\mathrm{ZnO}$ in the presence of Poly (sodium 4-styrensulfonate (PSSS). Thus, it was seen that $\mathrm{ZnO}$ micro sized rods with tunable aspect ratios under hydrothermal conditions. It were clarified that the morphological 
variations of those $\mathrm{ZnO}$ microstructures were highly dependent on the PSSS concentration. Keeping the PSSS concentration relatively low in this study $\left(0-0.5 \mathrm{~g} . \mathrm{L}^{-1}\right)$, the aspect ratios of the $\mathrm{ZnO}$ micro sized rods obtained are reduced due to selective adsorption of the in the polar $\mathrm{ZnO}(001)$ crystal plane by increased polymer amount.

In this study, the effect of PSSS concentration between 150$750 \mathrm{mg} \mathrm{L}^{-1}$ as a synthetic additive on $\mathrm{ZnO}$ crystallization was investigated and the effects of temperature, reactant concentration and ultra-sonication power on morphology, size and BET surface area of $\mathrm{ZnO}$ were also investigated using Taguchi experimental design.

\section{Materials and Method}

The route of the study was decided by applying the Taguchi method. The $\mathrm{ZnO}$ characterization process, which was synthesized using the conditions of the decided experiments, was applied. Using the levels created by the experimental design, the effects of the parameters are examined with the help of the MiniTab program, based on the findings with characterization (Length and width in SEM photos and BET specific surface areas) obtained in only nine experiments.

\subsection{Materials}

The reactants, zinc nitrate hexahydrate $\left(\mathrm{ZnNO}_{3} \cdot 6 \mathrm{H}_{2} \mathrm{O}\right)$ and hexamethylentetramine (HMT) and the additive, Poly (sodium 4styrensulfonate) (PSSS) were purchased from the Sigma-Aldrich ( $>99.0 \%$ pure). The molecular weight of PSSS is 70,000 g. The type II water used for doing experiments and cleaning experimental was produced with the Merck Millipore Elix Essential 10.

Crystallization experiments were performed with a $250 \mathrm{~mL}$ double-jacket reactor. The temperature control of the reactor was carried out with a circulating oil bath (Polyscience - AP07R-20A12E). The circulating oil bath was controlled by a probe that measures the temperature inside the reactor used. Reactor has been mixed using a magnetic stirrer (IKA, C-MAG - HS7). The temperature, conductivity and $\mathrm{pH}$ of experiments were recorded directly to a computer with the multimeter (WTW, 9420). The ultrasonic homogenizator, Sonics - VCX500 was used for ultrasonication.

\subsection{Method}

The reactants were heated the desired temperature before the mixing in the reactor. The zinc oxide production experiments were obtained spontaneously in the reactor at constant temperature. During these experiments, ultra-sonication (US) was applied $5 \mathrm{~s}$ per $15 \mathrm{~s}$ in reactor. Reactant mixing process has been waited for ten minutes after PSSS was added into the reactor. Experimental system is given Figure 1.

In the experimental design, Taguchi method was used (Simsek et al., 2013). L9 ( $\left.4^{3}\right)$ orthogonal design was preferred, thus number of experiment is reduced. In Table 1, parameters and levels have been given and also in Table 2, details of experiments have been shown.

Table 1. Parameters used in the experiments and their levels

\begin{tabular}{l|c|c|c}
\hline \multicolumn{1}{c|}{ Parameters } & Level & Level & Level \\
& $\mathbf{1}$ & $\mathbf{2}$ & $\mathbf{3}$ \\
\hline PSSS amount $(\mathrm{mg} / \mathrm{L})$ & 150 & 450 & 750 \\
\hline Ultrasonication Power $(\%)$ & 20 & 30 & 40 \\
\hline Reactant Concentration $(\mathrm{mM})$ & 15 & 30 & 45 \\
\hline Temperature $\left({ }^{\circ} \mathrm{C}\right)$ & 65 & 75 & 85 \\
\hline
\end{tabular}

Table 2. Details of Experiments

\begin{tabular}{l|c|c|c|c}
\hline $\begin{array}{l}\text { Exp. } \\
\text { Code }\end{array}$ & $\begin{array}{c}\text { PSSS } \\
\text { amount } \\
(\mathbf{m g} / \mathbf{L})\end{array}$ & $\begin{array}{c}\text { US } \\
\text { Power } \\
(\mathbf{\%})\end{array}$ & $\begin{array}{c}\text { [Reactant] } \\
(\mathbf{m M})\end{array}$ & $\begin{array}{c}\text { Temp. } \\
\left({ }^{\circ} \mathbf{C}\right)\end{array}$ \\
\hline Exp1 & 150 & 20 & 15 & 65 \\
\hline Exp2 & 150 & 30 & 30 & 75 \\
\hline Exp3 & 150 & 40 & 45 & 85 \\
\hline Exp4 & 450 & 20 & 30 & 85 \\
\hline Exp5 & 450 & 30 & 45 & 65 \\
\hline Exp6 & 450 & 40 & 15 & 75 \\
\hline Exp7 & 750 & 20 & 45 & 75 \\
\hline Exp8 & 750 & 30 & 15 & 85 \\
\hline Exp9 & 750 & 40 & 30 & 65 \\
\hline
\end{tabular}

\subsection{Characterization}

Scanning Electron Microscopy (SEM) photographs has been taken in LEO $1430 \mathrm{VP}$.

The Brunauer, Emmett and Teller (BET) surface area measurements was used to determine the specific surface area of the synthesized samples. Quantachrome Instruments - Novatouch Lx4 has been used for these analyses. All samples were degassed at $80{ }^{\circ} \mathrm{C}$ and helium atmosphere for 3 hour. Multipoint BET analysis has been used in calculations for each measurement.

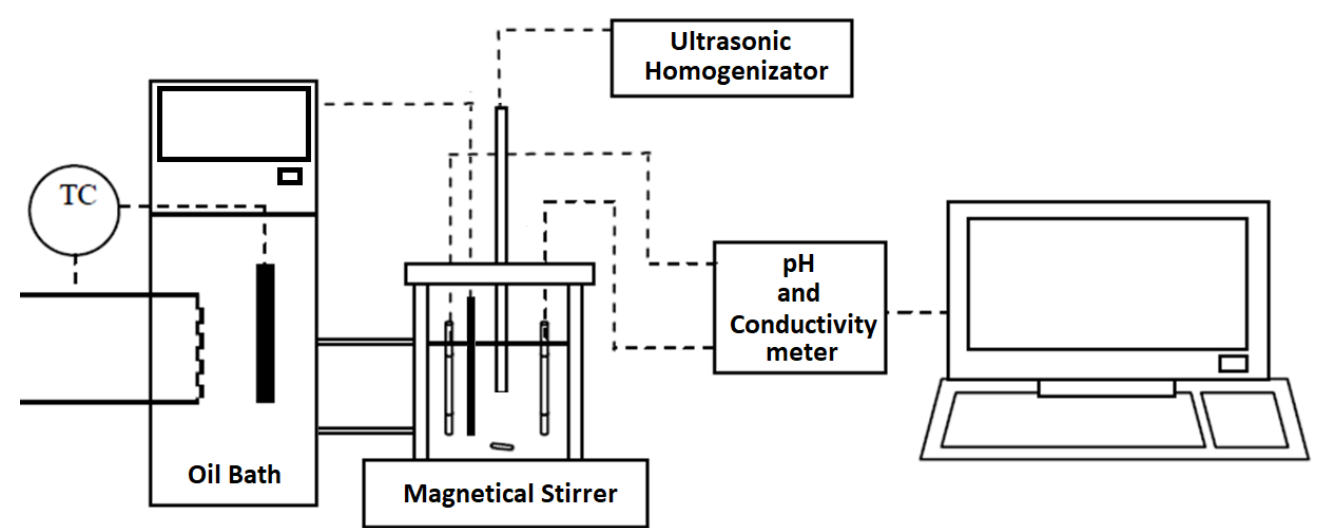




\section{Results}

SEM photographs of the experiments were used to determine the size of each sample in statistical analysis. Minimum investigation number was about hundred and called frequency. Detailed statistical analysis was given in a Table 3 for samples. Besides, a graphical size distribution for length and width is given on the SEM photographs in Figure 2, Figure 3 and Figure 4.

Table 3. Statistical analyses of crystal sizes, and BET surface area values

\begin{tabular}{llccccccc}
\hline \multirow{2}{*}{ Experiment } & Parameter & $\begin{array}{c}\text { Frequency } \\
\text { (number) }\end{array}$ & $\begin{array}{c}\text { Average } \\
\text { (nm) }\end{array}$ & $\begin{array}{c}\text { St. Dev. } \\
\text { (nm) }\end{array}$ & $\begin{array}{c}\text { Min. } \\
\text { (nm) }\end{array}$ & $\begin{array}{c}\text { Median } \\
\text { (nm) }\end{array}$ & $\begin{array}{c}\text { Max. } \\
(\mathbf{n m})\end{array}$ & $\begin{array}{c}\text { BET } \\
(\mathbf{m} / \mathbf{g})\end{array}$ \\
\hline \multirow{2}{*}{ Exp1 } & Length & 105 & 312.57 & 98.33 & 162.16 & 288.29 & 657.66 & 53.4 \\
& Width & 103 & 140.30 & 41.70 & 81.08 & 135.14 & 342.34 & 58.3 \\
\hline \multirow{2}{*}{ Exp2 } & Length & 110 & 211.63 & 64.35 & 90.09 & 216.22 & 396.40 & 25.4 \\
& Width & 103 & 185.87 & 39.69 & 99.10 & 189.19 & 306.31 & 22.1 \\
\hline \multirow{2}{*}{ Exp3 } & Length & 108 & 291.37 & 81.28 & 153.15 & 279.28 & 585.59 & 22.5 \\
& Width & 101 & 123.54 & 31.14 & 63.06 & 117.12 & 207.21 & 18.5 \\
\hline \multirow{2}{*}{ Exp4 } & Length & 103 & 249.72 & 54.35 & 135.14 & 243.24 & 432.43 & 14.6 \\
& Width & 105 & 206.61 & 50.21 & 117.12 & 198.20 & 387.39 & 12.2 \\
\hline \multirow{2}{*}{ Exp5 } & Length & 107 & 252.42 & 72.31 & 117.12 & 243.24 & 459.46 & 21.2 \\
& Width & 108 & 209.29 & 46.00 & 126.13 & 207.21 & 369.37 & 18.1 \\
\hline \multirow{2}{*}{ Exp6 } & Length & 101 & 487.91 & 80.23 & 315.32 & 486.49 & 765.77 & 24.0 \\
& Width & 108 & 288.37 & 64.07 & 162.16 & 283.78 & 441.44 & 21.1 \\
\hline \multirow{2}{*}{ Exp7 } & Length & 91 & 268.10 & 59.88 & 128.21 & 256.41 & 538.46 & 18.9 \\
& Width & 102 & 204.50 & 35.46 & 128.21 & 205.13 & 333.33 & 23.0 \\
\hline \multirow{2}{*}{ Exp8 } & Length & 95 & 378.27 & 69.87 & 230.77 & 384.62 & 666.67 & 2.0 \\
& Width & 125 & 305.33 & 67.59 & 141.03 & 307.69 & 474.36 & 3.2 \\
\hline \multirow{2}{*}{ Exp9 } & Length & 118 & 705.60 & 283.83 & 198.20 & 675.68 & 1558.56 & 4.4 \\
& Width & 111 & 370.91 & 141.47 & 144.14 & 360.36 & 981.98 & 4.9 \\
\hline
\end{tabular}
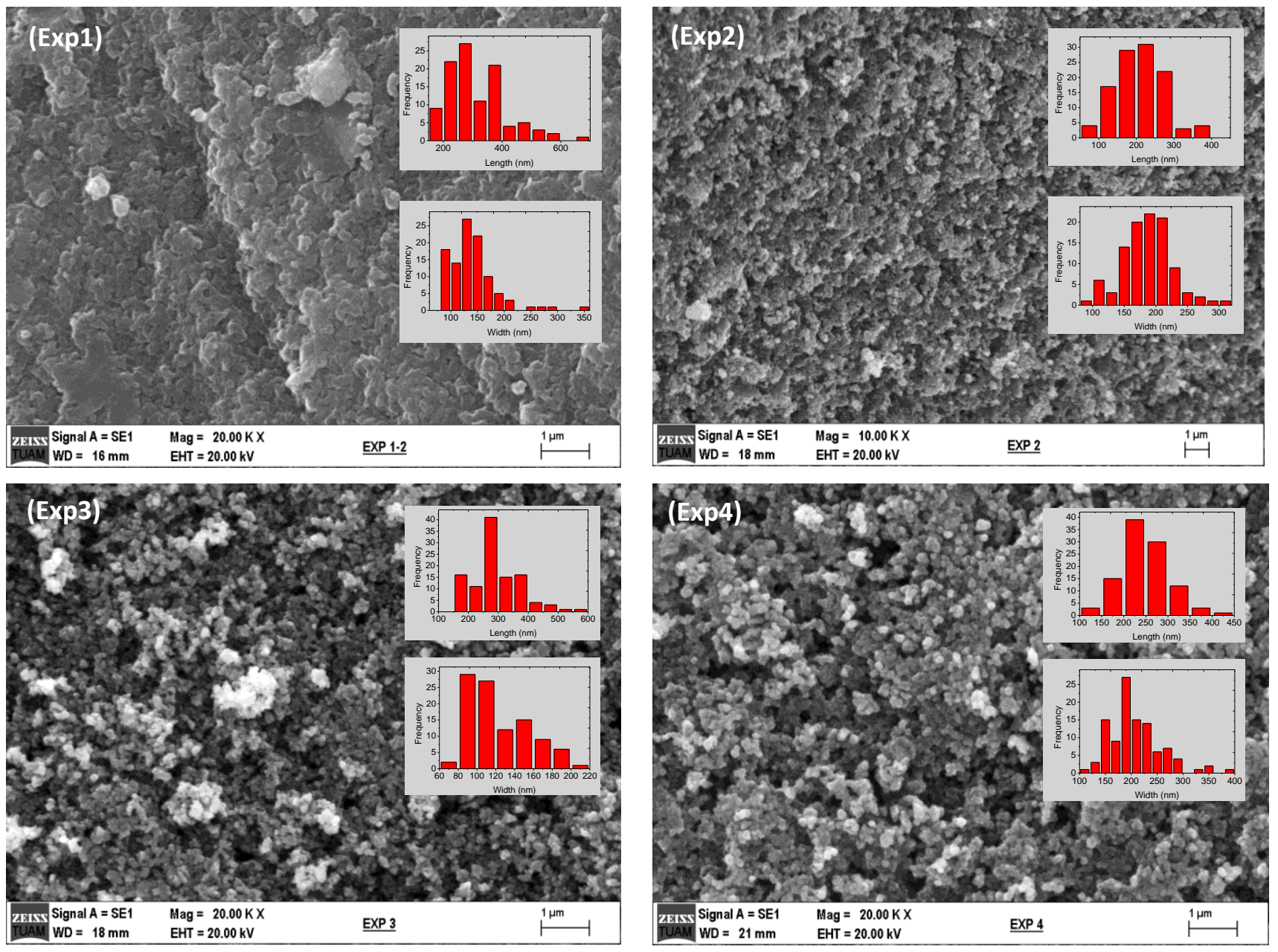

Figure 2. SEM photographs and size distributions of the materials: Exp1, Exp2, Exp3, and Exp4 

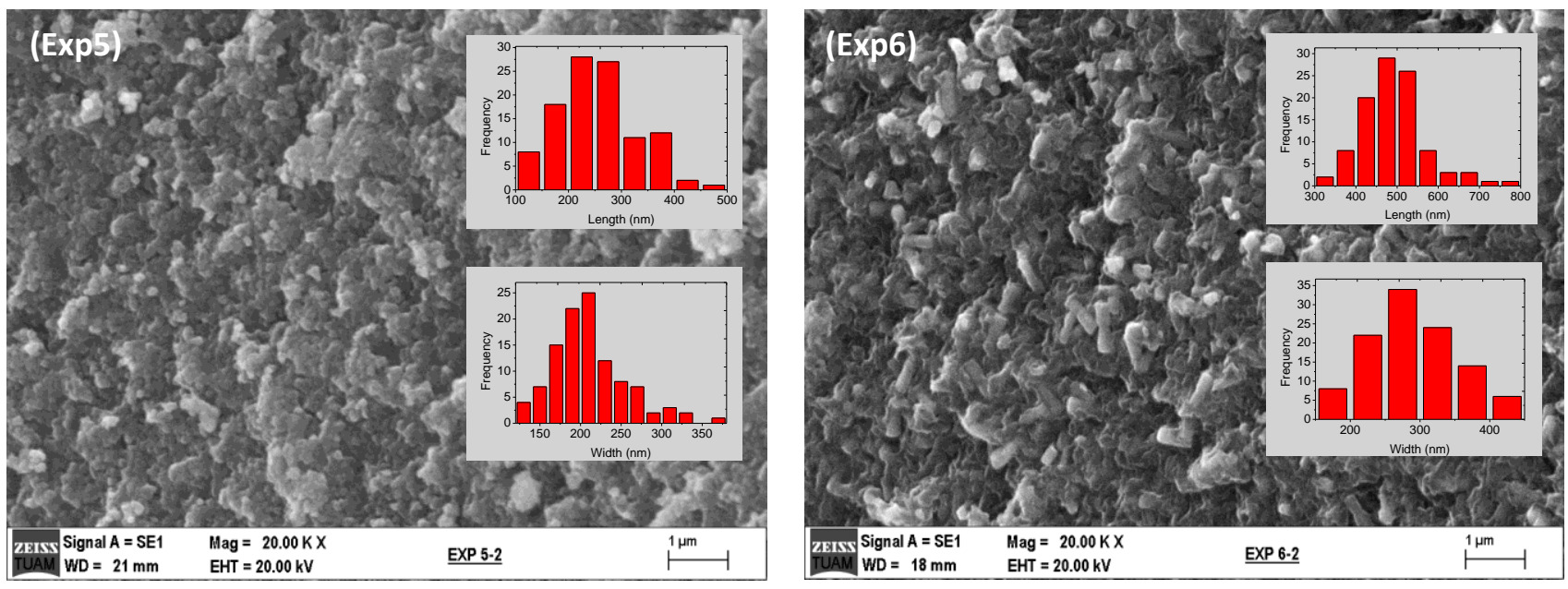

Figure 3. SEM photographs and size distributions of the materials: Exp5, and Exp6

As a result of measurements made using the Exp1 SEM photograph in Figure 2, the mean length $\left(\mathrm{L}_{\mathrm{ave}}\right)$ and mean width $\left(\mathrm{W}_{\text {ave }}\right.$ ) were found to be $312.6 \pm 98.3 \mathrm{~nm}$ and $140.3 \pm 41.7 \mathrm{~nm}$, respectively. Among the measured lengths, the value of the largest crystal was $657.7 \mathrm{~nm}$, and the value of the smallest crystal was $162.2 \mathrm{~nm}$. Similarly, the smallest one among the width values was $81.08 \mathrm{~nm}$ and the largest one was 342.34 (Table 3 and Figure 2). BET surface areas of the Exp1 were measured 53.4 and $58.3 \mathrm{~m}^{2} / \mathrm{g}$.
From the Exp2 SEM images given in Figure 2, result of the measurements obtained Lave and Wave values were found to be $211.6 \pm 64.4 \mathrm{~nm}$ and $185.9 \pm 39.7 \mathrm{~nm}$, respectively. As a result of the measurements made from the SEM image, it was seen that the length value changed between $90.1 \mathrm{~nm}$ and $396.4 \mathrm{~nm}$, and the width value changed between $99.1 \mathrm{~nm}$ and $306.3 \mathrm{~nm}$. (Table 3 and Figure 2). BET surface areas of the Exp2 were 25.4 and $22.1 \mathrm{~m}^{2} / \mathrm{g}$.
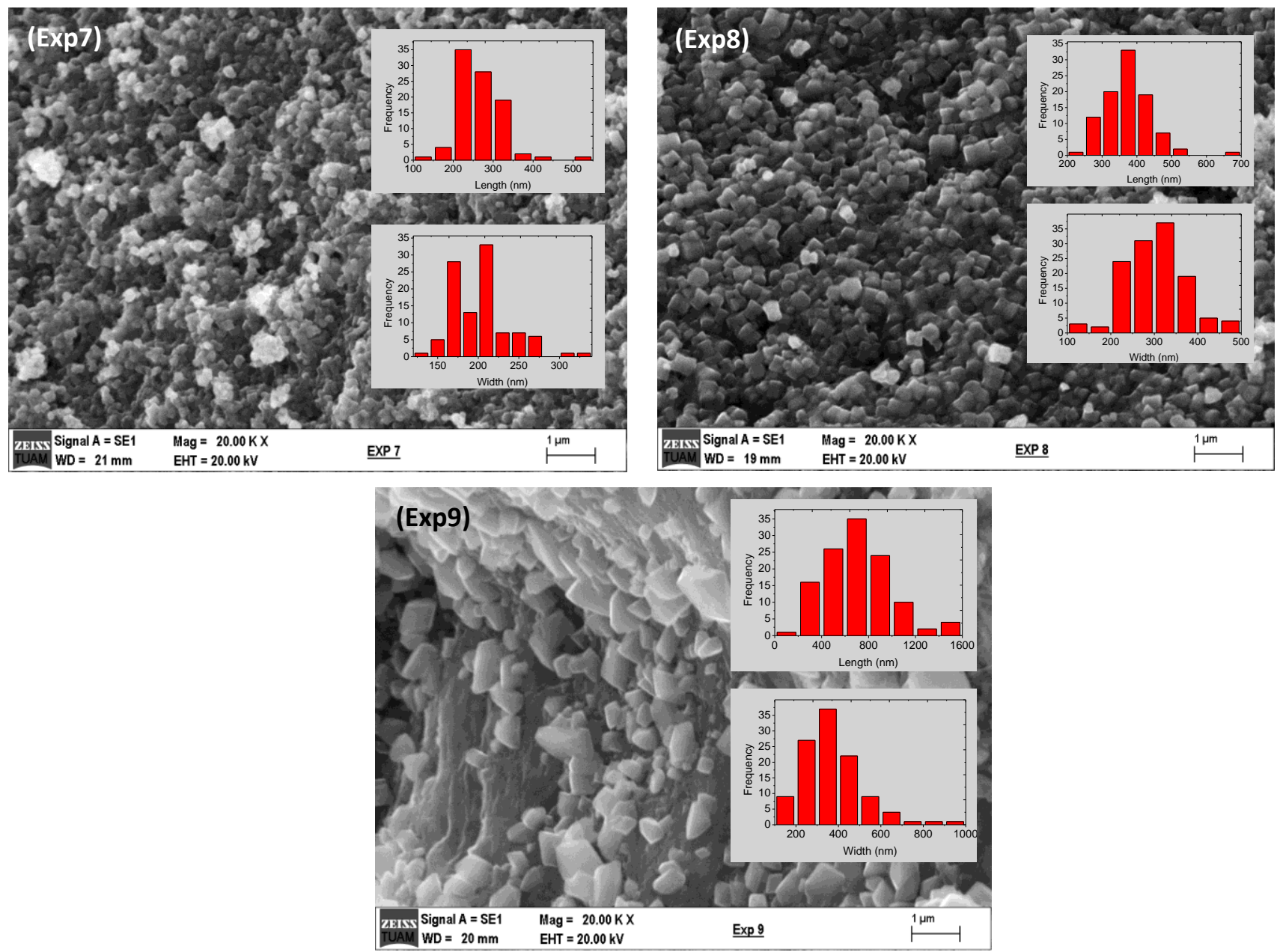

Figure 4. SEM photographs and size distributions of the materials: Exp7, Exp8, and Exp9 
$\mathrm{L}_{\mathrm{ave}}$ and $\mathrm{W}_{\mathrm{ave}}$ values obtained using SEM images from the synthesized Exp3 sample were calculated as $291.4 \pm 81.3 \mathrm{~nm}$ and $123.5 \pm 31.1 \mathrm{~nm}$, respectively. The length value varies between $153.1 \mathrm{~nm}$ and $585.6 \mathrm{~nm}$, while the width value varies between $63.1 \mathrm{~nm}$ and $207.2 \mathrm{~nm}$ (Table 3 and Figure 2). Two different analyzes of the Exp3 sample were made and the BET specific surface areas were found to be $22.5 \mathrm{~m}^{2} / \mathrm{g}$ and $18.5 \mathrm{~m}^{2} / \mathrm{g}$..

$\mathrm{L}_{\text {ave }}$ and $\mathrm{W}_{\text {ave }}$ values calculated by examining the SEM image for Exp4 were $249.7 \pm 54.4 \mathrm{~nm}$ and $206.6 \pm 50.2 \mathrm{~nm}$, respectively. It can be seen that while the length value is between $135.1 \mathrm{~nm}$ and $432.4 \mathrm{~nm}$, the width value is between $117.1 \mathrm{~nm}$ and $387.4 \mathrm{~nm}$. (Table 3 and Figure 2). The BET surface area values of the Exp4 sample were determined as $14.6 \mathrm{~m}^{2} / \mathrm{g}$ and $12.2 \mathrm{~m}^{2} / \mathrm{g}$ in the analyses.

The length values of $252.4 \pm 72.3 \mathrm{~nm}$ and $209.3 \pm 46.0 \mathrm{~nm}$, respectively, corresponded to the $\mathrm{L}_{\mathrm{ave}}$ and $\mathrm{W}_{\text {ave }}$ values of the synthesized Exp5 sample. As a result of the examination, it was determined that the smallest length value was $117.1 \mathrm{~nm}$, the biggest lenght value was $459.5 \mathrm{~nm}$, while the smallest width value was $126.1 \mathrm{~nm}$, and biggest width value was $369.4 \mathrm{~nm}$ (Table 3 and Figure 3). Measured BET specific surface areas of the Exp4 sample were $21.2 \mathrm{~m}^{2} / \mathrm{g}$ and $18.1 \mathrm{~m}^{2} / \mathrm{g}$.

As can be seen in Figure 3, $\mathrm{L}_{\text {ave }}$ and $\mathrm{W}_{\text {ave }}$ values for Exp6 were found to be $487.9 \pm 80.2 \mathrm{~nm}$ and $288.4 \pm 64.1 \mathrm{~nm}$, respectively. Length value was changed between $315.3 \mathrm{~nm}$ and $765.8 \mathrm{~nm}$. Width value was changed between $162.2 \mathrm{~nm}$ and 441.4 $\mathrm{nm}$ (Table 3). The size distributions of the Exp6 material in Figure 3 are given for both length and width. BET surface area values of the sample were $24.0 \mathrm{~m}^{2} / \mathrm{g}$ and $21.1 \mathrm{~m}^{2} / \mathrm{g}$.

For the Exp7 sample, the $\mathrm{L}_{\text {ave }}$ value, $268.1 \pm 59.9 \mathrm{~nm}$, and the $\mathrm{W}_{\text {ave }}$ value $204.5 \pm 35.5 \mathrm{~nm}$ presented in Table 3 were found using the SEM image in Figure 4. The result of the examination on Figure 4 is given in Table 4. In the same manner, it is given in Table 3 that the width value varies between $128.2 \mathrm{~nm}$ and 333.3 $\mathrm{nm}$ and the BET surface areas of the sample measured $18.9 \mathrm{~m}^{2} / \mathrm{g}$ and $23.0 \mathrm{~m}^{2} / \mathrm{g}$.

As a result of the SEM images investigated for the Exp8 sample (Figure 4), $\mathrm{L}_{\text {ave }}$ and $\mathrm{W}_{\text {ave }}$ were achieved to be $378.3 \pm 69.9$ $\mathrm{nm}$ and $305.3 \pm 67.6 \mathrm{~nm}$, respectively. Length value was differed between $230.8 \mathrm{~nm}$ and $666.7 \mathrm{~nm}$. The measured width of the Exp8 sample differed between $141.0 \mathrm{~nm}$ and $474.4 \mathrm{~nm}$. BET surface areas of the Exp8 were $2.0 \mathrm{~m}^{2} / \mathrm{g}$ and $3.2 \mathrm{~m}^{2} / \mathrm{g}$ (Table 3 and Figure 4).

For Exp9 (Figure 4), $\mathrm{L}_{\text {ave }}$ and $\mathrm{W}_{\text {ave }}$ values have been found $705.6 \pm 283.8 \mathrm{~nm}$ and $370.9 \pm 141.5 \mathrm{~nm}$ respectively. Length value was differs between $198.2 \mathrm{~nm}$ and $1558.6 \mathrm{~nm}$, besides width value was differs between $144.1 \mathrm{~nm}$ and $982.0 \mathrm{~nm}$ (Table 3 and Figure 4). BET surface areas of the sample were $4.4 \mathrm{~m}^{2} / \mathrm{g}$ and 4.9 $\mathrm{m}^{2} / \mathrm{g}$.

The obtained values are used in the Taguchi analysis in response, thereby clarifying the effects of the parameters for the levels studied.

\section{Discussion}

In this section, the main effect diagrams for length, width and BET surface area are examined and information is given about the effects of the parameters. Thus, it is clarified that which parameter will most effective the result during material synthesis in this study.
The most effective parameter on the average length of the synthesized $\mathrm{ZnO}$ crystals is ultra-sonication power and it is determined that the zinc oxide crystals produced grow as the ultrasonication power increases. Another important factor on the average length of zinc oxide crystals is the amount of additive and it is observed that as the amount of additive increases, the length value of $\mathrm{ZnO}$ crystals increases. As the reaction temperature increased, the average length of the zinc oxide crystals decreased. Considering the reaction concentration, it can be said that higher molarity reactant should be used for $\mathrm{ZnO}$ synthesis at a smaller length (Figure 5).

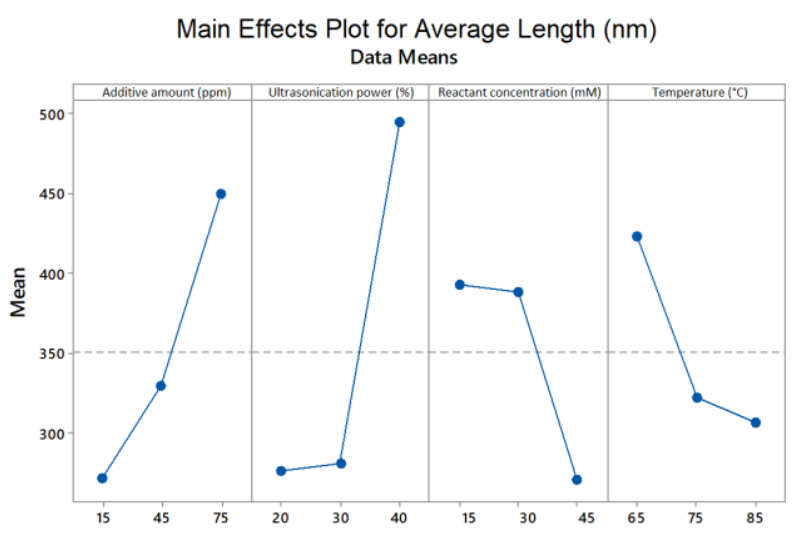

\section{Figure 5. Main effects plot for average length (nm)}

It is determined that the most effective parameter is the additive amount on the average width of the synthesized zinc oxide crystals and that as the concentration of the additive increases, the width of the zinc oxide crystals produced increases. Another important factor on the average width of the zinc oxide crystals is the ultra-sonication power and it is observed that the enrichment of the zinc oxide crystals increases as the ultrasonication power increases. As the reaction temperature increased, the average width of the zinc oxide crystals decreased. Considering the reaction concentration, it can be said that higher molarity should be used for zinc oxide synthesis at a smaller width (Figure 6).

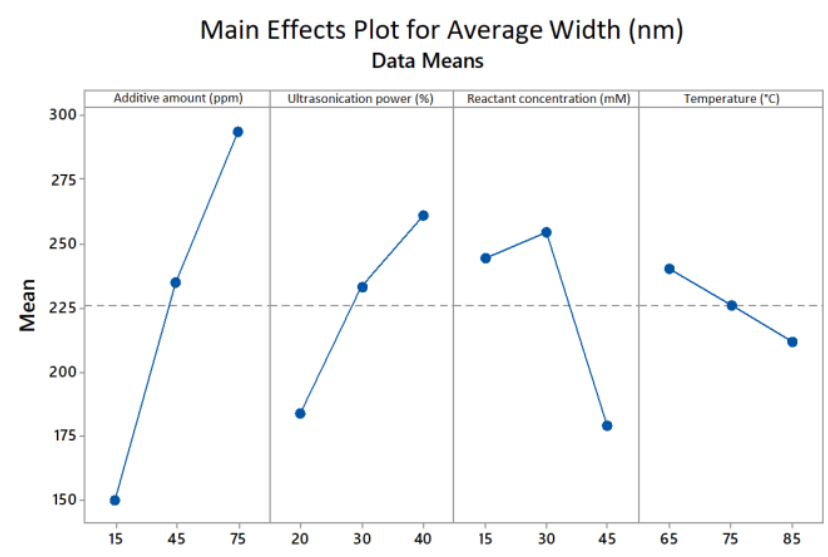

\section{Figure 6. Main effects plot for average width $(\mathrm{nm})$}

The most effective parameter on the surface area of the synthesized zinc oxide crystals is the additive amount and it is determined that the surface area of the zinc oxide crystals produced decreases as the amount of additive increases. The second important factor on the surface area of the zinc oxide crystals is the reaction temperature, and as the reaction 
temperature increases, the surface area of the zinc oxide crystals decreases. Considering the reaction temperature and reaction concentration, it can be said that higher molarity reactant and ultra-sonication power should be used for zinc oxide synthesis with larger surface area (Figure 7).

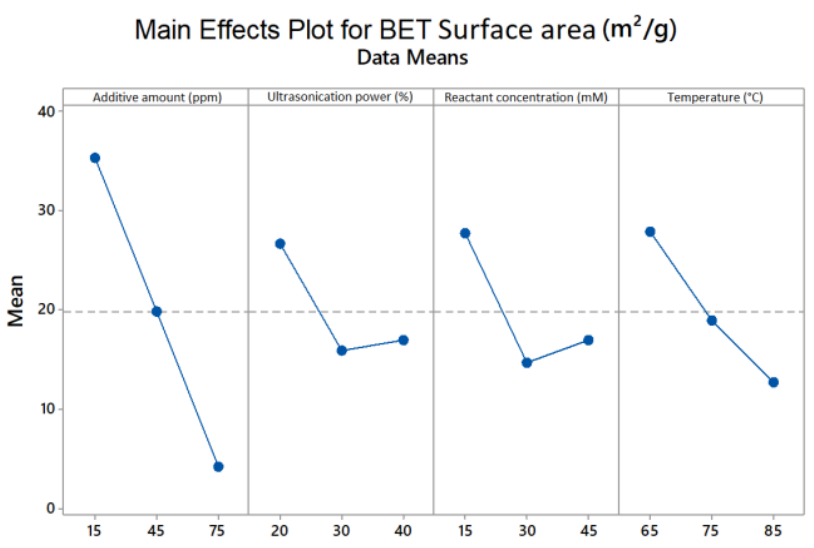

Figure 7. Main effects plot for BET surface area $\left(\mathrm{m}^{2} / \mathrm{g}\right)$

\section{Conclusion}

A summary of the results obtained is listed below:

As a result of Taguchi experimental design for both width and surface area, the most effective parameter was found to be PSSS polymer used as additive. For length value, the most effective parameter was found to be ultra-sonication power.

Surface areas of zinc oxide materials decrease with the effect of increasing additive concentration. This result is supported by the increase in length and width values with increasing additive amount.

With increasing ultra-sonication power, both the length and the width of $\mathrm{ZnO}$ crystals increase. By the side of, the results of the applied Taguchi Experimental Method also support the knowledge that the growing particle is caused a decrease in the specific surface area value.

\section{Acknowledge}

The authors are grateful to the Çankırı Karatekin University, Project Administration Unit for their financial support of this research (Project number: MF060416B28).

\section{References}

Akin, B. and Akyüz, T. (2020). Antibacterial effect of $\mathrm{ZnO}$ crystals on foodborne pathogens: an optimization study, Journal of Microbiology, Biotechnology and Food Sciences, 10:(3), 484-489.

Akin, B. and Oner, M. (2012). Aqueous pathways for formation of zinc oxide particles in the presence of carboxymethyl inulin. Res Chem. Intermed., 38, 1511-1525.

Akin, M.B. and Oner, M. (2013). Photodegradation of methylene blue with sphere-like $\mathrm{ZnO}$ particles prepared via aqueous solution, Ceramics International, 39, 9759-9762.

Bao, Y. Gao, L. Feng, C. Ma, J. and Lyu, S. (2021). Systematically controlled synthesis of shape-selective $\mathrm{ZnO}$ superstructures via sonochemical process, Materials Science and Engineering: B, 263. 114887.
Goswami, M., Adhikary, N. C. and S. Bhattacharjee, (2018). Effect of annealing temperatures on the structural and optical properties of zinc oxide nanoparticles prepared by chemical precipitation method, Optik, 158, 1006-1015.

Intaphong, P. Phuruangrat, A. Yeebu, H. Akhbari, K. Sakhon, T. Thongtem, S. and Thongtem, T. (2021). Sonochemical Synthesis of $\mathrm{Pd}$ Nanoparticle/ZnO Flower Photocatalyst Used for Methylene Blue and Methyl Orange Degradation under UV Radiation, Russian Journal of Inorganic Chemistry, 66(14), 2123-2133.

Jay Chithra, M., Sathya, M. and Pushpanathan, K. (2015). Effect of $\mathrm{pH}$ on Crystal Size and Photoluminescence Property of $\mathrm{ZnO}$ Nanoparticles Prepared by Chemical Precipitation Method, Acta Metall. Sin. (Engl. Lett.), 28, 394-404.

Palms, D. Norwig, J. and Wegner, G. (2007). Electrochemically Induced Growth of Zinc Oxide, Chem. Phys. Chem., 8, 22602264.

Pholnak, P. Sirisathitkul, C. Danworaphong, S. and Harding, D. (2013). Sonochemical Synthesis of Zinc Oxide Nanoparticles Using an Ultrasonic Homogenizer, Ferroelectrics, 455, 1520.

Sahai, A. and Goswami, N., (2014). Structural and vibrational properties of $\mathrm{ZnO}$ nanoparticles synthesized by the chemical precipitation method, Physica E: Low-dimensional Systems and Nanostructures, 58, 130-137.

Satdeve, N.S. Ugwekar, R.P. Bhanvase, B.A. (2019). Ultrasound assisted preparation and characterization of Ag supported on $\mathrm{ZnO}$ nanoparticles for visible light degradation of methylene blue dye, Journal of Molecular Liquids, 291, 111313.

Simsek, B. Ic, Y. T. and Simsek, E. H. (2013). A TOPSIS-based Taguchi optimization to determine optimal mixture proportions of the high strength self-compacting concrete, Chemometrics and Intelligent Laboratory Systems, 125, 1832.

Sun, L., Zhao, D., Song, Z., Shan, C., Zhang, Z., Li, B. and Shen, D. (2011). Gold nanoparticles modified $\mathrm{ZnO}$ nanorods with improved photocatalytic activity, Journal of Colloid and Interface Science, 363(1), 175-181.

Türemen, M., Demir, A. and Gokce, Y. (2021). The synthesis and application of chitosan coated $\mathrm{ZnO}$ nanorods for multifunctional cotton fabrics, Materials Chemistry and Physics, 268, 124736.

Yang, Y. and Kim, K. (2021). Simultaneous acquisition of current and lateral force signals during AFM for characterising the piezoelectric and triboelectric effects of $\mathrm{ZnO}$ nanorods, Sci. Rep., 11, 2904.

Yu, J. Li, C. and Liu, S. (2008). Effect of PSS on morphology and optical properties of $\mathrm{ZnO}$, Journal of Colloid and Interface Science, 326(2), 433-438. 